\title{
KHARISMA KYAI DALAM ORGANISASI PENDIDIKAN PESANTREN TRADISIONAL
}

\author{
Umi Musaropah \\ Dosen STAI Yogyakarta \\ mimusaropa@gmail.com
}

\begin{abstract}
abstrak: Organisasi pesantren sangat kompleks karena ragam pendidikan yang diselenggarakan. Oleh karena, peran kyai sebagai pimpinan kahrismatik di dalamnya sangat dibutuhkan agar penyelenggaraan pendidikan bisa berkelanjutan. Penelitian kualitatif pada Pondok Pesantren At-Tanwir di Kabupaten Bojonegoro ini menggunakan instrumen pengumpulan data berupa; observasi, wawancara mendalam dan dokumentasi. Untuk validasi data ditentukan melalui perpanjangan waktu penelitian dan persilangan hasil berdasar kategori alat penelitian.
\end{abstract}

Kata kunci; organisasi, pendidikan, pesantren salaf.

Abstract: Islamic boarding schools (pesantren) are very complex because of the variety of education held. Therefore, the role of the clerics as a charismatic leader in them is needed so that education can be sustainable. Qualitative research at pesantren At-Tanwir in Bojonegoro Regency uses data collection instruments in the form of; observation, in-depth interviews and documentation. For data validation, it was determined through an extension of the research time and the results crossing based on the research tool category.

Keywords : organization, education, salaf pesantren

\section{A. Pendahuluan}

Keberadaan pesantren sebagai lembaga pendidikan ini sejak awal memiliki sifat yang lentur dan fleksibel, sehingga pada kenyataannya mampu menyesuaikan diri dengan kehidupan masyarakat. Pada awalnya, lembaga pendidikan pesantren memusatkan pengajarannya kepada alQur'an dan Hadits. ${ }^{1}$ Musaropah kemudian mencatat adanya perkembangan zaman telah mendorong lembaga pendidikan tradisional itu membuka diri terhadap perkembangan ilmu pengetahuan dan teknologi. Pesantren tidak lagi membatasi diri pada pengajaran pendidikan al-Qur'an dan Hadits saja, akan tetapi telah menyesuaikan diri dengan keadaan yakni dengan cara menyelenggarakan pendidikan umum.

${ }^{1}$ Karel A. Steenbrink, Pesantren Madrasah Sekolah; Pendidikan Islam Dalam Kurun Waktu (Jakarta: LP3ES, 1986), h.10. 
Inilah bentuk respon pesantren untuk memenuhi kebutuhan masyarakat yang semakin berkembang dan maju. ${ }^{2}$

Meski demikian Nugroho telah menyimpulkan bahwa kualitas sumber daya manusia dan manajemen internal perlu pembenahan. 3 Dalam kaitan madrasah yang seide dengan pesantren, ia mengutip dari hasil penelitian Depdikbud yang menyebutkan setidaknya ada 3 (tiga) wilayah sumber masalah dalam madrasah. Kecukupan dan kecakupan sarana prasarana pendukung pembelajaran serta standar pengelolannya, belum terpenuhi secara maksimal terutama madrasah swasta. Tata kelola internal atau manajemen internal madrasah belum terlaksana dengan baik. Terakhir, relevansi, mutu dan daya saing madrasah belum memadai.

Bagi santri, organisasi juga bisa menjadi salah satu sarana yang menumbuhkan rangsangan belajar. Meski ada perbedaan jenjang, namun bisa berkaca pada penelitian Kurnia tentang pengaruh keaktifan organisasi terhadap indeks prestasi mahasiswa di perguruan tinggi. Faktornya adalah pada kualitas aktivis itu sendiri mulai dari kefahaman mereka dalam berorganisasi, niat ikut berorganisasi, motivasi dan tata cara para aktivis yang bersangkutan dalam membagi waktu dengan perkuliahan supaya memiliki dua predikat, yaitu berpredikat menjadi aktivis kampus dan sekaligus lulus dengan berpredikat cumlaude atau memperoleh nilai terbaik dalam waktu sesingkat-singkatnya.4

Salah satunya adalah Pondok Pesantren At- Tanwir, Talun, Sumberrejo Kabupaten Bojonegoro. Pondok itu juga diakui sebagai lembaga pendidikan dari masyarakat, oleh masyarakat, dan untuk masyarakat. Pendidikan dari masyarakat adalah pendidikan yang berasal

2 Umi Musaropah, "Pemberdayaan Masyarakat Dalam Penyelenggaraan Pendidikan Anak Usia Dini Berbasis Pesantren,” aș-șibyan, Jurnal Pendidikan Guru Raudlatul Athfal, Vol.1, No.2, Tahun 2016, h. 177-185, http://jurnal.uinbanten.ac.id/ index.php/assibyan/article/view/203

3 Taufik Nugroho, "Analisis Manajemen Pendidikan Terhadap Kualitas Madrasah Indonesia," Jurnal Ulumuddin Volume 6, Nomor 2, Desember 2016, h. 80-87

4 Heri Kurnia, "Pengaruh Keaktifan Berorganisasi Terhadap Indeks Prestasi Kumulatif Mahasiswa Universitas Cokroaminoto Yogyakarta," Academy Of Education Journal Pendidikan Pancasila dan Kewarganegaraan Vol. 5 No.2 Juli 2014, h. 91-103, https://jurnal.ucy.ac.id/index.php/fkip/article/view/120/123 
dari masyarakat setempat, dimana pendidikan tersebut menjadi kebutuhan masyarakat yang ada di sekitar pesantren At-Tanwir. Pada saat itu, keberadaan pesantren sebagai lembaga pendidikan Islam memang sangat dibutuhkan oleh masyarakat setempat. Kondisi masyarakat yang sudah mengarah kepada khurafat dan cenderung kemaksiatan, yang sudah tidak mengenal tatanan moral dan sebagainya, menjadikan pesantren sebagai lembaga untuk mengkader dan mengevaluasikan masyarakat dari keadaan tersebut.

Partisipasi masyarakat juga dalam gotong royong bersama dalam upaya pendanaan, perencanaan, pembelajaran, dan lain-lain, dengan harapan purta/putrinya dapat memperoleh pendidikan yang layak. Pendidikan oleh masyarakat memiliki peranan yang sangat besar terhadap keberlangsungan penyelenggaraan pendidikan di Pondok Pesantren AtTanwir, karena tanpa adanya dukungan dari masyarakat pondok tersebut tidak akan ada seperti saat ini.5

Maka pendidikan di sini bukan berasal atas (pemerintah) topdown, melainkan pendidikan tersebut berasal dari masyarakat sebagai lembaga pendidikan Islam, Pondok Pesantren At-Tanwir menawarkan/memberikan program-program pendidikan yang sesuai dengan kebutuhan masyarakat dalam menghadapi era globalisasi. Hal ini dapat terlihat secara jelas dari program yang ditawarkan antara lain: 1) dalam pendidikan formal Pondok pesantren ini telah memiliki RA, setingkat dengan Tk, MI (setingkat dengan SD), MTs (setingkat dengan SLTP), MA (setingkat dengan SMA), serta Program Takhasus (yang setingkat dengan Perguruan Tinggi). Sedangkan untuk lembaga nonformal meliputi: Madrasah Diniyah (awal, wustho, 'Ulya), serta Majelis Taklim. ${ }^{6}$

Struktur yang demikian luas telah menuntut ada organisasi pendidikan yang mendukungnya. Organisasi sendiri dalam Islam adalah

5 Ibid.; Umi Musaropah, "Penyelenggaraan Pendidikan Berbasis Masyarakat di Pondok Pesantren At-Tanwir, Talun, Sumberejo, Bojonegoro (1992-2004)," Proceedings Seminar Nasional Pendidikan Penilaian Kinerja Guru dalam Era Sertifikasi, UCY, 14 Juni 2012, h. 81-88

6 Ibid. 
sebuah keharusan. Demikian Wahono menyatakannya.7 Dengan menyitir Q.S. as-saff (61):4, hal itu merupakan perintah yang harus ditaati oleh orang yang beriman.

Fauzi menemukan secara teoritik, organisasi pesantren bisa berbentuk kompleks atau berbentuk sederhana. ${ }^{8}$ Penelitian ini berniat mengeksplorasi lebih lanjut tentang organisasi pesantren sehingga diketahui peran kyai sebagai pimpinan di dalamnya. Hal itu sesuai yang disarnakan oleh Pemimpin yang dilahirkan pondok pesantren adalah pemimpin yang mempunyai kredebilitas dan integritas diri dalam memegang amanah kepemimpinan, artinya dapat menciptakan pemimpin yang religius. 9 Budaya organisasinya juga menunjang seperti yang ditemukan oleh Dedik dalam penelitiannya di pesantren luar Jawa. Budaya Organisasi menjadi faktor utama keberhasilan pendidikan di Pesantren sebagai: identitas, penyatu; dan komitmen kepada organisasi dan kelompok. ${ }^{10}$

Karena termasuk dalam penelitian kualitatif, maka pengumpulan datanya bertumpu pada tiga instrumen. Ketiganya adalah observasi, wawancara mendalam dan dokumentasi. Untuk validasi data ditentukan melalui perpanjangan waktu penelitian dan persilangan hasil berdasar kategori alat pengumpulnya.

\section{B. Organisasi Pendidikan}

Sepanjang perkembangnnya, pengorganisasian sebagai fungsi manajemen memiliki pengertian berbeda. Pengertian tersebut disebabkan oleh perbedaan latarbelakang keahlian para pakar yang memberikan pengertian itu, serta dipengaruhi oleh kondisi lingkungan dalam menerapkan fungsi pengorganisasian tersebut.

7 Joko Wahono, "Pentingnya Organisasi Dalam Mencapai Sebuah Tujuan," Academy Of Education Journal Pendidikan Pancasila dan Kewarganegaraan Vol. 5 No.1 Januari 2014, h. 71-79, https://jurnal.ucy.ac.id/ index.php/fkip/article/view/113/116

8 Faruq Tri Fauzi, "Manajemen Organisasi Pondok Pesantren, Edukasi," Volume o1, nomor O1, Juni 2013: $h$. 75- O91

9 Abdullah Aminuddin Aziz, "Memahami Organisasi Di Lingkungan Pesantren," Al Ta'dib, Volume 4 Nomor 2 Januari 2015, h. 173-191.

${ }^{10}$ Dedik, Budaya Organisasi Pondok Pesantren Tarbiyah Islamiyah Ar-Raudhatul Hasanah Paya Bundung Medan, Analytica Islamica, Vol. 4, No. 2, 2015, h. 323-35o 
Longenecher secara umum mendefinisikan pengorganisasian sebagai aktivitas menetapkan hubungan antara manusia dengan kegiatan yang dilakukan untuk mencapai tujuan. Pengertian ini menjelaskan bahwa kegiatan pengorganisasian berkaitan erat dengan upaya melibatkan orangorang ke dalam kelompok, dan upaya melakukan pembagian kerja di antara kelompok, untuk melaksanakan kegiatan sesuai dengan apa yang telah direncanakan dalam rangka mencapai tujuan yang telah direncanakan sebelumnya. ${ }^{11}$

Istilah pengorganisasian dapat diuraikan ke dalam dua pengertian, yaitu: dalam arti statis, organisasi sebagai wadah kerjasama sekelompok orang yang bekerja sama, untuk mencapai tujuan tertentu. Dalam arti dinamis, organisasi sebagai suatu sistem atau kegiatan sekelompok orang untuk mencapai tujuan tertentu. ${ }^{12}$ Dalam masalah ini, Nanang Fattah juga mengemukakan pengertian organisasi yakni: pertama organisasi diartikan sebagai lembaga atau kelompok fungsional, misalnya sebuah perusahaan, sebuah sekolah, sebuah perkumpulan, badan-badan pemerintah. Kedua, merujuk pada proses pengorganisasian yaitu bagaimana pelerjaan diatur dan dialokasikan di antara para anggota, sehingga tujuan organisasi dapat tercapai secara efektif. Sedangkan organisasi sendiri diartikan sebagai kumpulan orang dengan sistem kerja sama untuk mencapai tujuan bersama. Dalam sistem kerja sama secara jelas diatur siapa menjalankan apa, siapa bertanggungjawab atas apa, arus komunikasi, dan memfokuskan sumber daya pada tujuan. Karakteristis kerjasama di sini dapat dilihat;

1. adanya komunikasi antara orang yang bekerjasama,

2. individu dalam organisasi tersebut memiliki kemampuan untuk bekerjasama, dan

3. kerjasama tersebut ditujukan untuk mencapai tujuan. ${ }^{13}$

${ }^{11}$ Sudjana, Manajemen, hlm. 105.

${ }^{12}$ Ibnu Syamsi, Pokok-pokok Organisasi dan Manajemen (Jakarta: Rineka Cipta, 1994), hlm. 13.

13 Nanang Fattah, Landasan Manajemen Pendidikan (Bandung: Remaja Rosdakarya, 2004), h.71; juga Hani Handoko, Manajemen (Yogyakarta: BPFE, 2001), h. 167 
Pengorganisasian menjadi proses pembagian kerja ke dalam tugastugas yang lebih kecil, membebankan tugas-tugas itu kepada orang yang sesuai dengan kemampuannya, dan mengalokasikan sumber daya, serta mengkoordinasikannya dalam rangka efektifitas pencapaian tujuan organisasi.

Adapun untuk mewujudkan pengorganisasian yang baik dan efektif bagi pencapaian tujuan maka perlu menerapkan beberapa azas antara lain adalah; (a) organisasi harus fungsional; (b) pengelompokan satuan kerja harus menggambarkan pembagian kerja; (c) organisasi harus mengatur pelimpahan wewenang dan tanggung jawab; (d) organisasi harus mencerminkan rentang kontrol; (e) organisasi harus mengandung kesatuan perintah; (f) organisasi harus seimbang dan fleksibel.

Dari sini dapat dilihat, bahwa pengorganisasian merupakan fungsi kedua manajemen yang tak kalah pentingnya dengan perencanaan. Pengorganisasian meliputi usaha-usaha departementalisasi yang merupakan spesialisasi dari segi organisasi sebagai suatu keseluruhan dan pembagian kerja, yakni spesialisasi para anggota organisasi. Pengorganisasian pendidikan merupakan suatu fungsi dalam manajemen pendidikan. Pengorganisasian ini harus dilaksanakan dalam rangka mencapai tujuan manajemen pendidikan yang telah dirumuskan. Oleh karena itu, organisasi pendidikan pada hakikatnya merupakan bagian integral dari dalam sistem manajemen.

\section{Organisasi Pesantren}

Pengorganisasian merupakan aktivitas menyusun dan membentuk hubungan-hubungan kerja antara orang-perorang sehingga terwujud suatu kesatuan usaha dalam mencapai tujuan yang telah ditetapkan. Di dalam pengorganisasian terlihat jelas adanya pembagian tugas, wewenang dan tanggungjawab secara rinci menurut bidang-bidang dan bagianbagian, sehingga terciptalah hubungan kerjasama yang harmonis dan lancar menuju terciptanya tujuan yang telah ditetapkan.

Dalam pengorganisasian ini yang perlu diperhatikan antara lain adalah bahwa pembagian tugas, wewenang, dan tanggung jawab hendaknya disesuaikan dengan pengalaman, pengetahuan dan 
keperibadian masing-masing orang yang diperlukan dalam menjalaknkan tugas tersebut. Adapun prosedur pengorganisasian dapat digambarkan sebagai berikut:

Pengorganisasian sebagai fungsi administrasi pendidikan menjadi tugas utama bagi para pemimpin pendidikan termasuk kyai. Sebagaimana telah kita ketahui bahwa dalam kegiatan sehari-hari di pesantren terdapat bermacam-macam jenis pekerjaan yang memelukan kecakapan dan tanggung jawab berbeda-beda. Keberagaman tugas dan pekerjaan semacam itu tidak mungkin dipikul seorang diri oleh kyai sebagai pemimpin pendidikan di pesantren. Dalam hal ini terletak bagaimana kecakapan seorang kyai mengorganisasi para ustadz dan stafnnya dalam menjalankan tugas sehari-hari sehingga tercipta hubungan kerjasama yang harmonis dan lancar.

Salah satu ustaz menjelaskan dengan detil bagaimana hal itu terjadi. Ketika seseorang masuk dalam struktur organisasi, orang tersebut telebih dahulu harus mendapat restu dari kyai, baru kemudian di tes, apakah orang tersebut memenuhi syarat untuk menjadi seorang ustadz ataukah tidak. Biasanya dalam pemilihan ini mencakup senioritas, pengalaman, dan kepribadian santri, yang jelas orang tersebut mau bekerja secara ikhlas dan Lilâhi Ta'âlâ.

At-Tanwir menggunakan 2 (dua) model kepengurusan yakni pengurus yang mengelola asrama/pesantren dan pengurus yang membawahi Madrasah, dan masing-masing pengurus tersebut memiliki wewenang dan otonom dalam menjalankan tugasnya. Kepengurusan di Pondok Pesantren sepenuhnya diserahkan oleh para santri senior meliputi piket, listrik, pengurus bagian keamanan, kesehatan, pengajaran, keterampilan dan lain-lain yang berada di bawah komando kyai. Adapun kepengurusan di Madrasah dibentuk berdasarkan kebutuhan dan diambil dari para ustadz melalui pemilihan. Pengurus madrasah ini memiliki tugas yang sangat berat yakni mengurusi bagaimana pendidikan itu berjalan sesuai dengan visi dan misi pesantren.

Di sini terlihat keunikan pesantren, di mana satu instansi pendidikan memiliki dua kepengurusan yang masing-masing memilik 
tugas dan wewenang yang berbeda. Seorang pengurus dalam menjalankan tugasnya tidak ada istilah apakah pekerjaan itu sudah sesuai dengan kompetensi atau belum. Karena, di sini yang terpenting orang tersebut mau menjalankan tugas sebagai bukti pengabdian kepada kyai dengan ikhlas. Pelayanan harus dianggap sebagai tugas kehormatan yang merupakan ukuran pengabdian dari santri. Status sebagai santri di pesantren dengan memilik fungsi sebagai medium guna menciptakan ketundukan kepada tata nilai yang berlaku di Pesantren ini.

Walaupun pengurus dibentuk untuk mencapai tujuan pendidikan pesantren, namun kekuasaan mutlak ada di tangan kyai. Karenanya, diakui atau tidak, betapapun demokratisnya susunan kepengurusan di pesantren, masih terdapat jurang tak terjembatani antara kyai serta keluarganya di satu pihak, dengan para santri dan ustadz di pihak lain. Kedudukan yang dipegang seorang kyai adalah kedudukan ganda yakni sebgai pengasuh dan pemilik pesantren serta secara kultural kedudukan ini sama dengan kedudukan bangsawan feodal.

Untuk melaksanakan hasil perencanaan dan pengorganisasian yang telah ditetapkan di Pesantren, pengasuh melakukan pembagian kerja kepada bawahan (ustadz dan lain-lain). Secara garis besar program kerjanya terbagi dalam dua kelompok besar, yakni program kerja pendidikan formal dan non formal.

Program kerja pendidikan formal (RA, MI, MTS, MA, Takhasus) meliputi:

1. Bagian umum

Program kerja yang dilakukan oleh bagian umum lembaga Pendidikan formal meliputi: 1) membuat dan mengisi buku program kerja madrasah; 2) membuat dan mengisi buku notula dan hadir rapat; 3) membuat dan mengisi buku statistik baik untuk ustadz maupun santri; 4) membuat dan mengisi buku tamu; 5) membuat dan mengisi buku uraian tugas guru; 6) mendokumentasikan buku panduan madrasah; 7) mendokumentasikan buku tata tertib santri ; 8) membuat surat-surat keputusan madrasah; 9) membuat dan mengisi daftar nilai latihan; 10) membuat buku raport; 11) membuat dan mengisi buku induk ustadz; 12) 
mengarsip surat masuk dan keluar; 13) melayani dan membuat surat keterangan yang berhubungan dengan kemadrasahan; 14) membuat pengumuman-pengumuman yang berkaitan dengan madrasah.

2. Bagian Kesiswaan

Program kerja bagian kesiswaan adalah 1) membantu guru dalam membina kepribadian santri agar dapat mencapai perkembangan yang optimal, 2) membentuk Pengurus Pelajar Madrasah (PPM), 3) memantau dan mengawasi perjalanan PPM, 3) membimbing dan mengarahkan kegiatan PPM, 4) menginstruksikan siswa dalam berbagai lomba, 5) membina siswa dan membuat kelompok berbakat di berbagai bidang yakni jurnalistik, kaligrafi, boga, merangkai janur dan lain-lain, 6) mengontrol penerbitan buletin dan mading, 7) mengembangkan kegiatan PPM, 8) mengadakan karya wisata, 9) membuat laporan kondisi siswa, 10) menyelenggarakan kegiatan aktivitas shalat berjamaah.

3. Bagian Pendidikan dan Pengajaran

Progam kerja bagian pendidikan dan pengajaran meliputi 1) membuat kalender pendidikan, 2) membuat pembagian tugas mengajar guru, 3) membuat jadwal pelajaran, 4) mendata secara lengkap program kegiatan ekstrakurikuler, 5) membatu pengasuh menyediakan tenaga pengajar, 6) mengatasi keadaan bila pelajaran kosong, 7) menyiapkan bahan ujian, 8) menyelenggarakan evaluasi belajar, 9) membuat laporan kerja kepada pengasuh setiap 1 bulan.

4. Bagian Kurikulum

Program kerja bagian kurikulum meliputi 1) membuat daftar pembagian tugas mengajar, 2) merancang kitab yang akan dijadikan referensi, 3) membuat program pencapaian kurikulum dan buku khusus, 4) menyediakan buku pegangan guru, 5) memantau kegiatan siswa, 6) membuat laporan kegiatan kepada Mudir Madrasah.

5. Bagian keuangan

Program kerja bagian keuangan meliputi 1) membuat RAPBP bulanan dan tahunan, 2) membuat dan mengisi buku kas bulanan dan tahunan, 3) menutup buku kas bulanan dan tahunan, 4) merekap nota dan kuitansi yang mmasuk dan keluar, 5) menerima uang pangkal yang telah 
disyahkan, 6) menerima SPP bulanan, 7) membuat buku kendali pengeluaran uang, 8) melakukan penagihan SPP bagi siswa yang menunggak, 9) mencatat penerimaan uang dan barang, 10) membuat buku kas harian madrasah, 11) membayar gaji kepada ustadz dan pegawai, 12) membuat berita acara gaji ustadz kepada mudir madrasah, 13) membuat laporan keuangan kepada mudir madrasah.

6. Bagian Hubungan Masyarakat

Progam kerja bagian humas meliputi 1) memberi informasi kemadrasahan kepada semua pihak yang berkepentingan, 2) membina hubunga baik dengan masyarakat sekitar, 3) menyampaikan surat-surat yang berkaitan dengan guru, pengurus, dan instansi terkait.

7. Bagian Penelitian dan Pengembangan

Progam kerja bagian Litbang ini meliputi 1) menggali kemungkinan pengembangan yang meliputi:; metode, pengajaran, kesiswaan, pendidikan dan pengajaran, kurikulum, serta bakat dan minat, 2) mengevaluasi faktor-faktor kelemahan yang ada pada lembaga madrasah, 3) memberdayakan SDM yang ada, 4) membuat laporan kepada audit madrasah.

Untuk program kerja pendidikan non formal (Madrasah Diniyah) PP At-Tanwir meliputi:

a. Program Kerja Umum

Program ini meliputi 1) mengadakan kegiatan Romadlon dan Pesantren Liburan, 2) mengadakan haflah akhirus-sanah, 3) mengadakan Orientasi dan pengenalan Pondok Pesantren.

b. Program kerja pengurus harian

1) Sekretaris

Bertugas 1) membuat papan bagan pengurus, 2) menertibkan surat dan mengarsipnya, 3) membuat jadwal piket kantor dan buku tamu, 4) menertibkan prndidikan santri, 5) membuat kartu santri, 6) membuat buku induk santri dan buku induk pengurus, 7) mempersiapkan rapatrapat, 8) membuat agenda kegiatan, 9) membuat grafik perkembangan jumlah santri, 10) menginventaris barang-barang milik produk pesantren.

2) Bendahara 
Bidang utamanya berkaitan dengan alur keuangan dalam peneyelenggaraan penddikan pesantren. Tugas utamanya adalah; mengatur keluar masuk uang, menertibkan pembayaran syahriyah dan makan, menangani pajak setrika.

3) Program Kerja Departemen

a) Departemen Keamanan dan Ketertiban

Mengusahakan keamanan dan ketertiban asrama,dengan realisasi 1) penanganan pintu gerbang, 2) menertibkan bunyi-bunyian dan buku-buku porno, 3) memberikan sanksi dan ta'zir bagi pelaku pelanggar, 4) membuat undang-undang yang berkaitan tentang keamnan dan ketertiban, 5) membuat tata tertib umum, 6) menertibkan izin pulang atau meninggalkan pondok, 7) membuat kartu izin pulang/meninggalkan pondok dan pemantauannya, 8) pemantauan penertiban administrasi izin, 9) penanganan kasus-kasus kehilangan dan penerimaan barang, 10) pemantauan hubungan putra-putri.

b) Departemen Kebersihan dan Kesehatan

Program kerja departemen ini meliputi 1) mengadakan dan mengkoordinasi ro'an, 2) menyediakan dan menertibkan peralatan kebersihan, 3) pengaturan jadwal dan piket kebersihan, 4) pengurusan pakaian kotor dan jemuran.

c) Departemen Pendidikan

Program ini meliputi 1) mewajibkan sholat berjamaah beserta wiridnya, 2) mengintensifkan kajian kitab, 3) sorogun Al-Qur'an, 4) mengintensifkan kegiatan muhadloroh/khitobah, 5) mengadakan wirid Qobla Magrib, 6) melakukan tahlil bersama setiap malam jum'at ba'da magrib, 7) mengintensifkan kegiatan managib ba'da subuh, 8) mengintensifkan kegiatan barzanji, kajian tajwid, dan fasholatan.

d) Departemen Keterampilan

Meningkatkan kegiatan santri dalam bidang seni dan keterampilan dengan realisasi; 1) Mengadakan kursus Tilawah, 2) mengadakan kursus kaligrafi yang bekerja sama dengan Assosiasi of kaligrafi At-Tanwir (ASSKAR), 3) Mengadakan kursus hadroh, 4) mengadakan kursus jurnalistik, 5) mengadakan kursus merangkai janur. 


\section{Kepemimpinan Pesantren}

Pondok Pesantren At-Tanwir bukanlah berbentuk yayasan, akan tetapi milik keluarga, oleh karena itu dalam pengelolaanya tidak dapat disamakan dengan lembaga lain, baik yayasan maupun lembaga profit lainnya. Kepemimpinan merupakan proses untuk mempengaruhi seseorang atau kelompok dalam usaha ke arah pencapaian tujuan dalam situasi tertentu. Dalam hal ini kepemimpinan meliputi pelaku verbal dan non verbal yang kemudian menjadi unsur komunikasi dalam proses pembuatan keputusan.

Di dalam Pondok Pesantren At-Tanwir terdapat kepemimpinan yang diperankan oleh kyai antara lain adalah:

1. Kepemimpinan Uswatun Hasanah

Kepemimpinan Uswatun Hasanah (teaching by example) merupakan bagian yang paling mendasar bagi seorang kyai. Sebagai patron yang selalu dianut baik kata maupun perbuatannya bagi para santrinya. Karena, kata-kata dan perbuatan kyai dapat menjadi pijakan bagi para santri dalam berbuat. Uswatun hasanah merupakan manifestasi kehidupan kyai dalam meniru kehidupan Nabi dan mencoba menghadirkan secara nyata dalam kehidupan sehari-hari.

Dampak dari kepemimpinan uswatun hasanah adalah menjadi efektif dalam memberi perintah terhadap para santri. Santri tidak mempersoalkan apakah perintah tersebut berat atau ringan, namun yang pasti perintah tersebut akan dikerjakan dengan baik. Dalam penuturan salah satu guru senior, Pola kempemimpinan yang digunakan di pondok pesantren At-Tanwir adalah uswatun hasanah, yakni kyai memberi contoh secara langsung kepada para santrinya kemudian para santri meniru apa yang dilihat dan dengar dalam kehidupannya sehari-hari. Karena hal ini, kyai memiliki karisma di depan para santri dan masyarakat umum.

Kyai berusaha menggalang kerja sama semua semua sumber daya yag ada dalam pesantren untuk mencapai suatu tujuan pendidikan, tujuan pendidikan tersebut disusun dari yang paling sederhana sampai yang paling kompleks tergantung dari ruang lingkup dan tingkat pendidikan yang dimaksud. Kehasan pengelolaan dapat dilihat dari tujuan, proses, 
dan orientasinya. Berdasarkan tujuannya, manajemen pendidikan pesantren yang harus senantiasa bermuara pada tujuan pendidikan, yaitu mengembangkan kepribadian dan kemampuan dasar peserta didik. Berdasarkan proses, manajemen pendidikan harus dilandasi sifat edukatif yang berkenaan dengan unsur manusia yang tidak semata-mata dilandasi prinsip mendidik. Sedangkan berdasarkan orientasinya, pendidikan pesantren tetap diorientasikan atau memusatkan orientasinya kepada santri peserta didik.

\section{E. Penutup}

Dalam pengeloaan sebuah organisasi pesantren yang kompleks, Peran kyai tidak berbeda jauh dari awal dikenalnya lembaga itu. Pada dasarnya kepemimpinan karismatik sangat cocok di terapkan di pondok pesantren. Hal ini dikarenakan, pesantren membutuhkan figur yang karismatik, dapat dicontohkan, dan dapat diteladani oleh para santri dan masyarakat sekitar.

Setiap orang yang diangkat menjadi pemimpin tentunya berdasarkan atas sejumlah kelebihan yang dimilikinya daripada orang yang dipimpin. Dalam keadaan tertentu dan pada waktu tertentu pula kelebihan yang dimilikinya dapat digunakan untuk bertindak sebagai pemimpin. Demikian juga kepemimpinan kharismatik yang banyak dimiliki oleh para kyai. Pada umumnya para kyai tersebut memiliki daya tarik yang begitu besar karena itu mereka memiliki pengikut dengan jumlah besar pula. Bahkan kyai seolah-olah memiliki kekuatan gaib yang merupakan pancaran dari nur ilahi. Karisma yang dimiliki tidak bergantung pada umur ataupun kekayaanya.

Kepemimpinan karismatik memiliki keunggulan yang dapat mengalahkan pribadi lain disekitarnya. Kekuatan pribadi seperti ini menimbulkan corak kepemimpinan yang sangat pribadi sifatnya, yang berlandaskan penerimaan masyarakat luar dan warga pesantren secara mutlak.

Pada tahap pertama pendirian dan perkembangan pesantren, sangat memerlukan kepemimpinan karismatik dengan segala sifat-sifatnya, akan tetapi pada tahap berikutnya banyak kerugian yang ditimbulkan antara 
lain adalah; pertama, munculnya ketidakpastian dalam perkembangan pesantren yang bersangkutan karena semua hal/persoalan tergantung pada keputusan pribadi sang pemimpin. Kedua, sulitnya bagi tenagatenaga pesantren untuk mencoba pola-pola pengembangan yang sekiranya belum diterima oleh kepemimpinan yang ada. Kesulitan ini adalah sukarnya membuat perkiraan tentang tanggapan yang akan diberikan oleh sang kyai atas sebuah usulan. Ketiga, pola pergantian kepemimpinan berlangsung secara tiba-tiba dan tidak direncanakan sehingga lebih banyak bersifat alami seperti meninggalnya sang pemimpin secara mendadak. ${ }^{14}$

Semua kerugian di atas tidak berarti kepemimpinan kharismatik harus dihilangkan sama sekali. Hal ini dikarenakan telah mengakar di pondok pesantren selama berabad-abad lamanya, melainkan perlu penerapan pola kepemimpinan yang lebih direncakan dan dipersiapkan sebelumnya secara matang. Oleh karena itu, sudah seharusnya karisma yang telah dimiliki semakin diperbuat dengan sifat dan sikap baru yang mampu mengeliminasi kerugian yang ada. Prinsip utama yang biasa digunakan adalah dengan memelihara hal yang baik yang selama itu telah ada, sambil mengembangkan hal baru yang lebih baik.

\section{Daftar Pustaka}

Aziz, Abdullah Aminuddin."Memahami Organisasi Di Lingkungan Pesantren," Al Ta'dib, Volume 4 Nomor 2 Januari 2015, h. 173-191.

Dedik. "Budaya Organisasi Pondok Pesantren Tarbiyah Islamiyah ArRaudhatul Hasanah Paya Bundung Medan.” Analytica Islamica, Vol. 4, No. 2, 2015: 323-35O.

Fattah, Nanang. Landasan Manajemen Pendidikan. Bandung: Remaja Rosdakarya, 2004.

Fauzi, Faruq Tri. "Manajemen Organisasi Pondok Pesantren”. Edukasi Volume 01, Nomor 01, Juni 2013, h. 075- 091

Handoko, Hani. Manajemen. Yogyakarta: BPFE, 2001.

Kurnia, Heri. "Pengaruh Keaktifan Berorganisasi Terhadap Indeks Prestasi Kumulatif Mahasiswa Universitas Cokroaminoto Yogyakarta." Academy of Education Journal Pendidikan Pancasila dan Kewarganegaraan Vol. 5 No.2 Juli 2014, h. 91-103, https://jurnal.ucy.ac.id/index.php/fkip/article/view/12O/ 123

Musaropah, Umi. "Pemberdayaan Masyarakat Dalam Penyelenggaraan Pendidikan Anak Usia Dini Berbasis Pesantren.” aș-șibyan, Jurnal

${ }_{14}$ Abdurrahman Wahid, Menggerakkan Tradisi (Yogyakarta: LKIS, 2001), h. 134. 
Pendidikan Guru Raudlatul Athfal, Vol.1, No.2, Tahun 2016, h. 177-185, http://jurnal.uinbanten.ac.id/index.php/assibyan/ article/ view/203

Musaropah, Umi. "Pengelenggaraan Pendidikan Berbasis Masyarakat di Pondok Pesantren At-Tanwir, Talun, Sumberejo, Bojonegoro (19922004)." Proceedings Seminar Nasional Pendidikan Penilaian Kinerja Guru dalam Era Sertifikasi, 14 Juni 2012, h. 81-88.

Pidarta, Made. Manajemen Pendidikan Indonesia. Jakarta: Bina Aksara, 1986.

Soepardi, Imam. Dasar-dasar Administrasi Pendidikan. Jakarta: Depdikbud, 1988.

Steenbrink, Karel A. Pesantren Madrasah Sekolah; Pendidikan Islam Dalam Kurun Waktu. (Jakarta: LP3ES, 1986), h.10.

Sudjana. Untuk Pendidikan Formal, Untuk Pengembangan Sumber Daya Manusia. Bandung: Falah Production, 2004.

Syamsi, Ibnu. Pokok-pokok Organisasi dan Manajemen. Jakarta: Rineka Cipta, 1994.

Wahid, Abdurrahman. Menggerakkan Tradisi. Yogyakarta: LKIS, 2001.

Wahono, Joko. "Pentingnya Organisasi Dalam Mencapai Sebuah Tujuan." Academy Of Education Journal Pendidikan Pancasila dan Kewarganegaraan Vol. 5 No.1 Januari 2014, h. 71-79, https://jurnal.ucy.ac.id/index.php/fkip/article/view/113/116 